\title{
Statistical analysis of sea accidents and breakdowns in the Polish Navy
}

\author{
Zbigniew Korczewski, \\ Polish Naval University
}

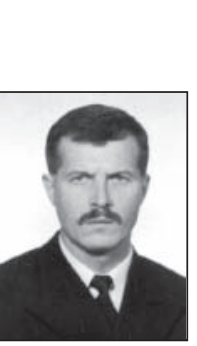

\begin{abstract}
This paper presents the results of systematic, statistical approach to naval accidents and breakdowns which occurred in the Polish Navy between years 1985 - 2004. Additionally, the author of this work has made an initial assessment of the human factor. Human errors, which appeared on considered warships in the examined period of time, have been analyzed in the overall number of accidents and breakdowns.
\end{abstract}

Keywords: naval accidents and breakdowns, statistical analysis, human factor

\section{INTRODUCTION}

A warship stands for a complex technical system, which comprises a lot of technical equipment, that operational reliability has a serious impact on her warfare ability $[2,4,6$, $12,13]$. During warfare there may happen partial or total loss in functioning mechanisms and installations, in a word - the occurrence of breakdowns.

Breakdowns of ship's technical equipment can be classified according to the occurrence of the following causes: the impact of enemies warfare agents, materials' defects and defects within the production process, constructional defects, technological defects in the process of renovation, excessive natural process of material's wear and tear, not fulfilling the requirements for operation and service of equipment, not taking security measures while storing dangerous cargoes e.g. explosive materials, petroleum products and other chemical components of serious fire hazard.

Failures which are caused by navigational mistakes or maneuverability represent the next group of possible reasons for ship accidents and breakdowns. But taking into consideration safety of a warship during combat missions as well as during daily operation it goes without saying that fires represent the greatest threat $[2,4,5,6,11]$. Despite the fact that fire very rarely leads the ship to sink, the destruction is usually very serious and always depends on the crew's training perfection in a damage control.

\section{STATISTICAL APPROACH TO NAVAL ACCIDENTS AND BREAKDOWNS}

Naval experiences show that even highly organized fleets struggle against accidents and technical breakdowns which couldn't be completely eliminated. This paper presents analysis of accidents and technical breakdowns which took place on warships of the Polish Navy between years 1985 $-2004$.

The considered accidents and technical breakdowns were divided into three time periods: years 1985 - 1990, years 1991 - 1998 and years $1999-2004$.

This division has been accepted taking into consideration geopolitical changes which had happened in Europe in the late 80 's, and the fact of joining Poland to NATO on March 12, 1999 which was related to them. These transformations have been reflected in the Polish Navy forces developmental plans spanning years up to 2012, whose main goal is to increase the operational potential within strict financial limits [1]. In these plans it was assumed that the increase of the operational potential would be based on replacement or modernization of presently possessed warships. As a consequence, the warships of outdated construction and the ones of which operation was not included in plans of state's strategic defense had been withdrawn from operation (among them landing crafts 770 and 771 type, submarines 641 type, destroyer 61MP type, some of cutters 205 type, submarine chaser $912 \mathrm{M}$ type), and replaced by, for instance, submarines "Kobben" type, guided missile frigates "Oliver Hazard Perry" type, logistic support ship "Kontradmirał Xavery Czernicki” or modernized warships such as rescue ship 570 type, minesweeper 206F and 207D type, mine transport - landing warship 767 type, guided missile warships 660 type, frigate $620 \mathrm{D}$ type. Moreover, building multi-purpose corvette 621 type has been started.

While analyzing consequences of these alterations it should be taken into consideration that a warship is a complex technical system, and if so, then everything should be done in order to interpret and modify regulations aiming at keeping its safety of floating in combat operation and daily action at the highest level. 
Statistical data prepared by the Polish Navy Commission of Warship Accidents and Breakdowns reveal that between years 1985 - 2004 there have been recorded 159 warship accidents and breakdowns and their overall structure examined in certain periods, taking into account the annual mean, is presented in Fig. 1.

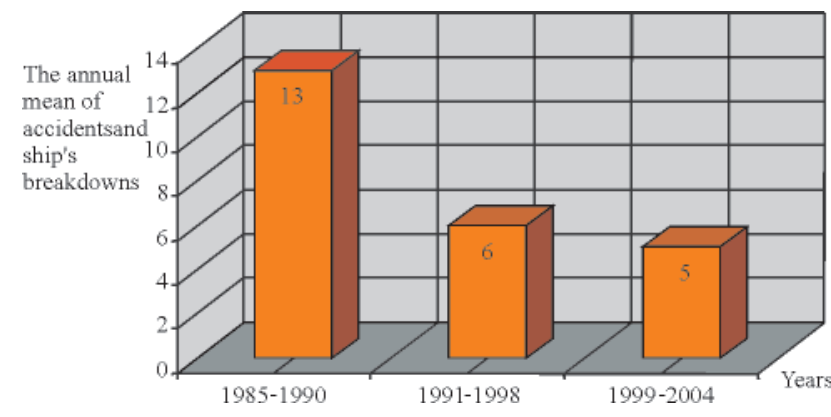

Fig. 1. The overall structure of accidents and ship's breakdowns between 1985 - 2004

The structure of accidents and technical breakdowns shown in Fig. 2 indicates that the most numerous are technical causes $[4,6]$. They constitute $65 \%$ of the whole number of accidents and breakdowns being the greatest losses in our Navy and they have increasing tendency.

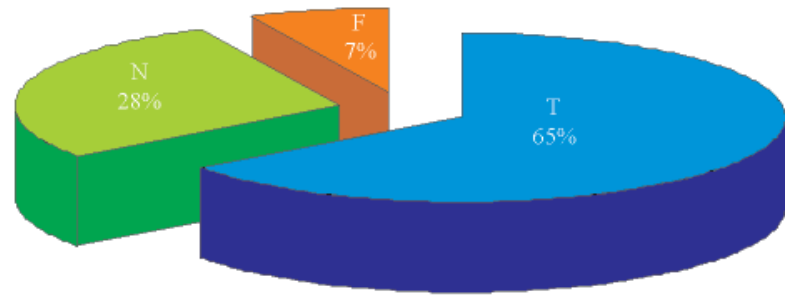

T - technical $\square \mathrm{N}$ - navigational $\square \mathrm{F}$ - fires

Fig. 2. The structure of accidents and breakdowns of ships between 1985 - 2004 expressed in percentage terms

Data shown by numbers $[4,6]$ given in Fig. 3 tell, that between $1985-2004$ there have been recorded different mean annual technical accidents and breakdowns.

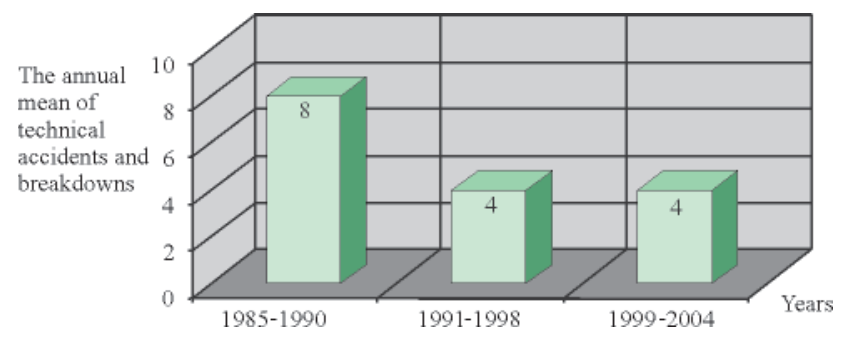

Fig. 3. The total number of the annual mean of technical accidents and breakdowns in years 1985 - 2004

Fig. 4 presents numerical data concerning causes of accidents and technical breakdowns between 1985 -2004, whereas figure 5 - their structure expressed in percentage terms.

By analyzing these data of breakdowns with relation to real causes, it should be stated, that the greatest number of breakdowns is observed due to defects of materials and technological production and defects during technological renovation. However, in the examined time period 19911998 initial decrease in number of accidents and technical breakdowns resulting from constructional defects was followed by their increase in the years $1999-2004$ and they account for the highest number of the total number of accidents and technical breakdowns in the analyzed period of time.

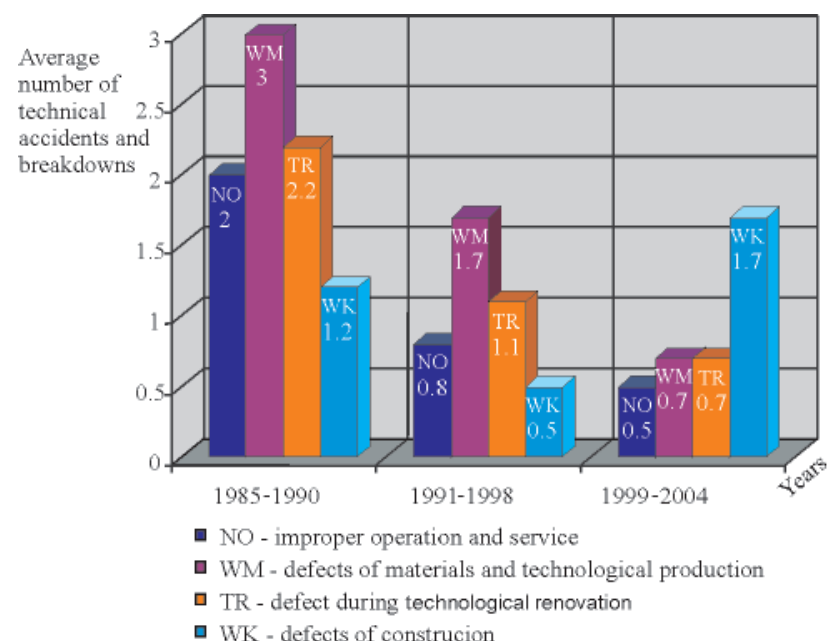

DTK- defects of construcion

Fig. 4. The causes of technical accidents and breakdowns in years 1985 - 2004

In the examined period of time spanning years 1985 - 2004, 103 accidents and technical breakdowns happened. From this analysis, concerning the percentage of particular causes of accidents and breakdowns, we should infer that still the highest number of breakdowns are recorded due to defects of materials and technological production which equal 34\% of the total number of technical accidents and breakdowns. Considerable amount of breakdowns results from defects of technological renovation, which constitute $25 \%$, although the number of technical accidents and breakdowns caused by improper operation and service still reach relatively high level, which amounts to $20 \%$ of total number of technical accidents and breakdowns and it is here where we can see the great considerable scope for action of the persons responsible for the safety of floating.

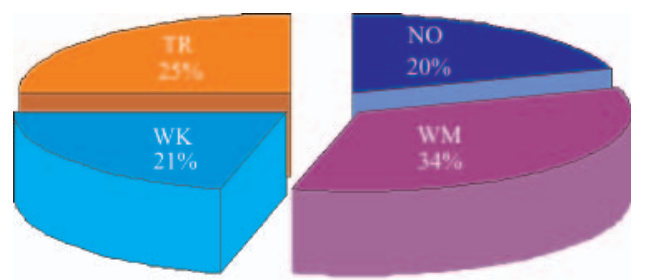

- NO - improper operation and service

- WM - defects of materials and technological production

- TR - defect during technological renovation

- WK - defects of construction

Fig. 5. The structure of technical accidents

and breakdowns in years 1985 - 2004 in percentage terms

Failures of ship's technical equipment also occur due to mistakes in navigation and maneuvering warships. Numerical data shown in Fig. 6 indicate that the most frequent causes of those breakdowns between 1985 -1990 were strikes on a quay and obstructions to navigation. The situation has changed between years 1999 - 2004, when grounding prevailed. It was mainly caused by improper maneuvering through main fairways (main navigable channels), taking more precisely, inaccurate assessments of the navigational situation made by the persons responsible for the safety of floating.

Analyzing the structure of accidents and warship failures in technical equipment resulting from navigational mistakes expressed in percentage terms and shown in Fig. 7, it could be observed that strikes on quays and obstructions to navigation constitute $35 \%$, whereas collisions with other ships $-30 \%$ of the total number of accidents and navigational breakdowns. Ship collisions and strikes on quays and obstructions to navigation 
are the consequence of human errors in maneuvering, failures of the propeller pitch control system and wrong decisions taken by the persons responsible for the safety of floating. The number of grounding grows as well, which equal $23 \%$ of the total number of accidents and breakdowns resulting from navigational mistakes and this process has increasing tendency.

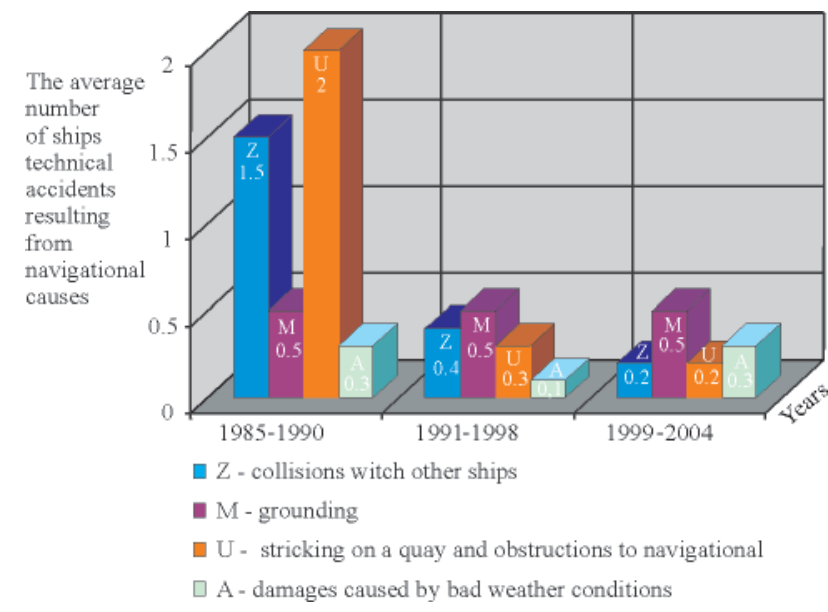

Fig. 6. The overal structure of accidents and ship's technical equipment resulting from navigational causes in years 1985-2004

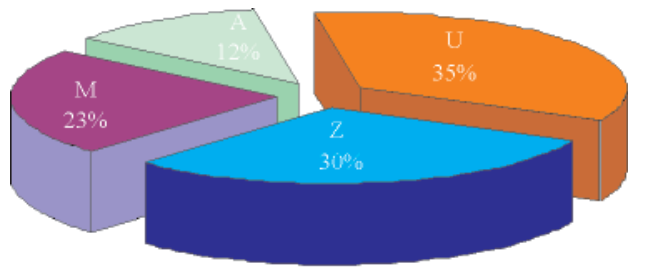

$$
\begin{aligned}
& \text { Z - collisions witch other ships } \\
& \text { M - grounding } \\
& \square \mathrm{U} \text { - stricking on a quay and obstructions to navigational } \\
& \square \mathrm{A} \text { - damages caused by bad weather conditions }
\end{aligned}
$$

Fig. 7. The structureof accidents and failures in ships technical equipment resulting from navigational mistakes between 1985 - 2004 expressed in percentage terms

Taking into consideration the structure of accidents and breakdowns between 1985 - 2004, it could be observed that fires amounted to $7 \%$ of their total number. They occurred primarily due to electrical failures in electrical installations, breakdowns in technical equipment and mechanisms, self ignition of pure oxygen coming into contact with oil - extracted materials (the crew was found partly at fault) and defects in firing. It may be concluded that such a small number of fires is probably related to crews' absolute compliance with fire - fighting regulations and established requirements regarding STCW 95 convention according to which, fire - fighting trainings of crews are carried out. Recently, crews of warships have undergone such trainings as well.

According to the statistical analysis placed in the elaborations as $[3,5,9]$ majority of accidents at sea (about $80 \%$ ) are caused by operation in which appear Human and Organizational Errors (HOE). Designing and constructing reasons constitute $20 \%$ of HOE. The rest of causes are due to operation reasons which depend on such factors as: culture of society, organization, human error and system - where it can be distinguished design standards, operation characteristics, information on operation characteristics for functional persons, weather factors and constructional characteristics of a warship. The potential causes of naval accident of the warship are illustrated in Fig. 8, which was created on the basis of [5].

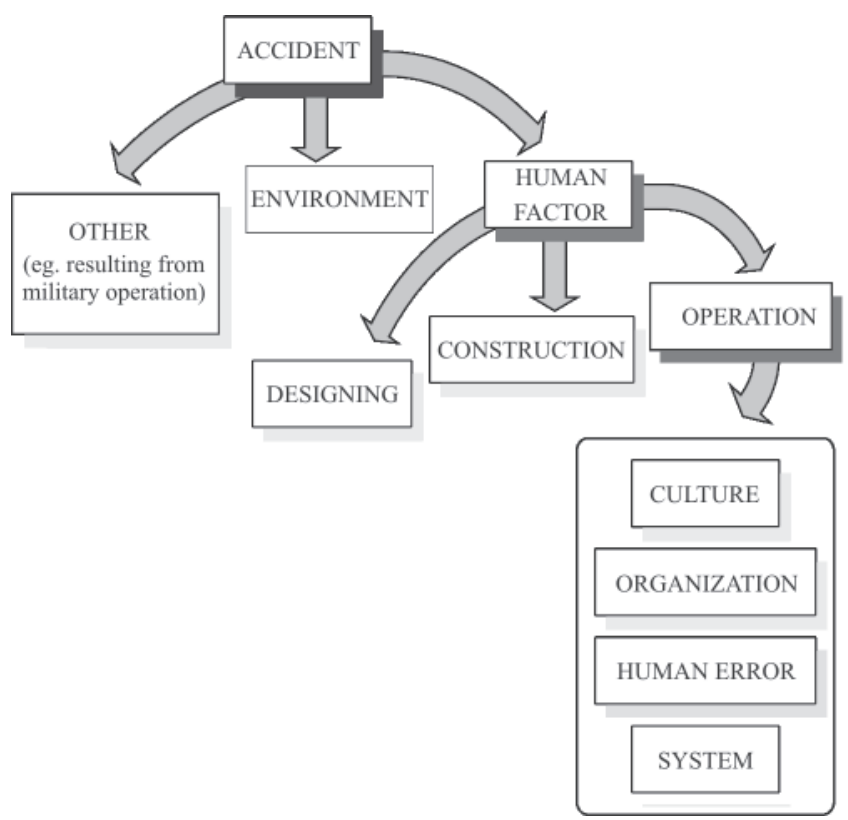

Fig. 8. The causes of naval accidents of a warship at sea

By means of surveys through the accidents and breakdowns occurring on warships of the Polish Navy between years 1985 -2004 , which are shown in figure 9, the author of this work has made initial assessment of human factor.

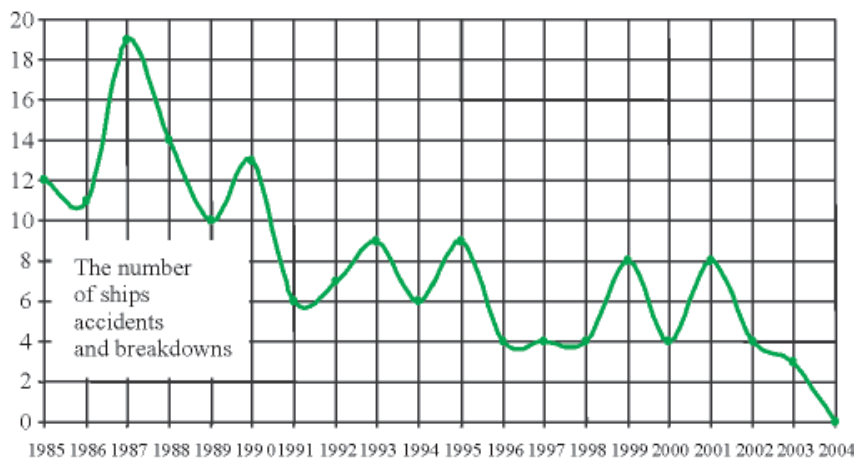

Years

Fig. 9. General number of warships accidents and breakdowns in the time period 1985 - 2004

Human errors, which appeared on warships in the examined period of time, were analyzed in the overall number of breakdowns, as shown in figure 10.

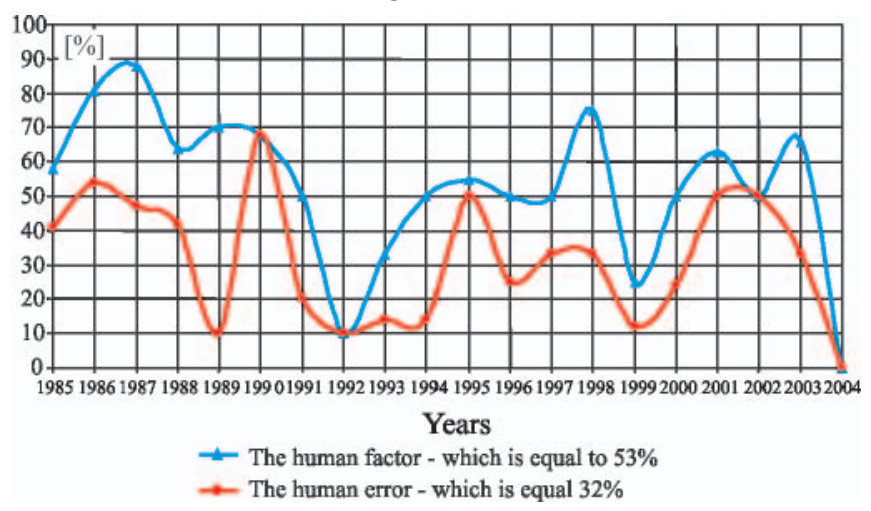

Fig. 10. The human factor and human error in total number of ships accidents and breakdowns in year between years 1985 - 2004

Numerical data presented on the foregoing graph provide information on the total mean of human factor in overall 
number of breakdowns on warships of the Polish Navy. The mean amounts to $53 \%$ and current values fluctuates between $88 \%$ in the year 1987 and $10 \%$ in 1992 . The cause of the rest of accidents and breakdowns was the widely interpreted marine environment. On average, a human error was the reason for $32 \%$ of total number of accidents and breakdowns and current values fluctuated between $68 \%$ in 1990 and $10 \%$ in 1992 . (data for 2004 were collected up to October, 2004 and were equal to $0 \%$ ).

Accidents and breakdowns of warships, which occurred as a result of human error, were mainly caused by excessive speed not adjusted to the surrounding navigational and maneuvering conditions, inaccurate maneuvering, improper operation and service of machines and warship technical equipment, carelessness, lack of proper assessment of the situation, improperly kept watch, and in some cases - even the bad routine.

It is common knowledge that the best form of schooling are training and exercises on a warship and group of warships at sea, after adequate theoretical and practical preparation of crews in their naval bases.

Taking into account that research carried out in our Navy between 1985 - 2004 it might be initially analyzed from the view of spending moto - hours ascribed to each warship. So called running hours of the main (propulsion) engines on three chosen types of warship in the years 1985 -2004, are illustrated in Fig. 11. From numerical data presented in this figure, we can infer that in the period of time spanning years 1985-2004 the time of real work of the main engines on the considered representatives was reduced by $30 \%$ or even $60 \%$ in relation to the year 1985 .

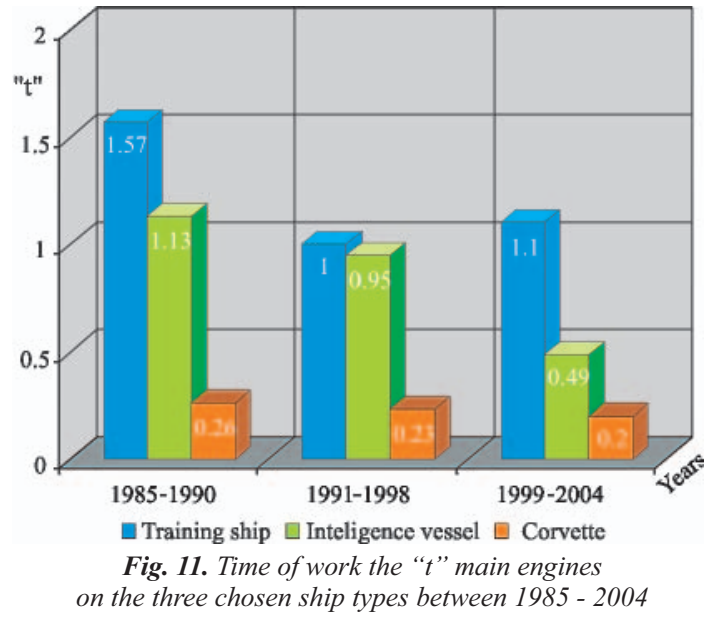

Besides, taking into account that the Polish Navy constitutes a vital element in the structure of state's defense $(528 \mathrm{~km}$ of the seashore protected), everything should be done in order to keep marine awareness in the country at the highest level for the sake of business in the Polish marine territory.

\section{CONCLUSIONS}

O From the carried out analyses of warship accidents and breakdowns between years 1985 - 2004 it can be assumed that the most frequent ones happened due to technical failures $(65 \%)$. They cause the greatest loss in the Polish Navy, and have an increasing tendency.

As a consequence of navigational mistakes, including grounding, the percentage of accidents and technical breakdowns is grooving as well. Maybe it would be advisable to use navigational simulator as a very useful aid to train crews more extensively at the Naval University in Gdynia.

The role of commanders as well as every member of a crew is enduring keeping operational ability at the highest level. It is inherently connected with safety of a warship. Nevertheless, all efforts should be made at every level of command in our Navy, which would aim at reducing human factor in overall number of accidents and technical breakdowns.

It is undoubtedly associated with training and financial aids, which should be taken into consideration.

\section{BIBLIOGRAPHY}

1. Dilling J., Sołkiewicz H.: Stan oraz zamierzenia $w$ dziedzinie rozwoju wojskowej techniki morskiej w MW RP. Przegląd Morski nr 2. Gdynia 2000

2. Gawlilienko A.: Wzrywopożarobjezopasnost korablia: probliemy inżjeniernoj podgotowki.- Morskoj Sbornik, $1997 \mathrm{nr} 8$

3. Jacobsen T.: A potential of reducing the risk of ship casualties by 50\%. Marine Technology V. Szczecin, 2003, pp $171-181$

4. Jakus B., Korczewski Z., Mironiuk W., Szyszka J., Wróbel R.: Obrona przeciwawaryjna okrętu, cz.1, Gdynia 2001

5. Kobyliński L.K.: Podstawy i filozofia bezpieczeństwa $w$ żegludze. $1^{\text {st }}$ Summer School Safety at Sea. Technical University of Gdańsk, Gdańsk 2001

6. Korczewski Z., Wróbel R.: Charakterystyka wypadków i awarii okrętowych środków technicznych. Przegląd Morski nr 2. Gdynia 2000, str.40-53

7. Miller D.: Damage control - an , insurance policy” navies neglect at their peril. International Defence Review. 5/1994

8. Mironiuk W., Pawlędzio A., Wróbel R. Trenażer do walki $z$ woda. Przegląd Morski nr 5. Gdynia 2003, str.14-30

9. Plewiński, L.: Wypadki na morzu, Szczecin 2000

10.Polska Norma. 1993. Stownik terminologiczny elektryki. Niezawodność, jakość obstugi. PN -93/N-50191

11. Protokoły z postępowań po awariach Głównej Komisji d.s. Wypadków i Awarii Okrętowych MW RP. 1985-2004

12.Turner S.C.: The US Navy In Review, Proceedings, may 2001, s. 78-84

13. Wysokiński W.: Analiza przyczyn awarii $i$ wypadków okrętowych zaistniatych w MW w latach 1985 - 1995. (praca dyplomowa Akademia Marynarki Wojennej). Gdynia1996

CONTACT WITH THE AUTHOR

Assoc. Prof. Zbigniew Korczewski

Mechanic-Electric Faculty, Polish Naval University

Śmidowicza 69

81-103 Gdynia POLAND

e-mail: zkorczewski@wp.pl 